\title{
The Polish Question Through the Eyes of Russian Liberal Constitutionalists on the Eve and During the January Uprising
}

\section{Yu. Gusman}

For citation: Gusman L. Yu. The Polish Question Through the Eyes of Russian Liberal Constitutionalists on the Eve and During the January Uprising. Vestnik of Saint Petersburg University. History, 2019, vol. 64, iss. 4, pp. 1213-1225. https://doi.org/10.21638/11701/spbu02.2019.403 (In Russian)

The article examines ideological positions of Russian liberal constitutionalists with regard to the Polish question in the 1860s. The author comes to the conclusion that mutual misunderstanding between Russian and Polish political writers stemmed from different perceptions of the Polish issue. While the Polish side supposed that it was necessary to restore "historic Poland" within the boundaries of the Polish-Lithuanian Commonwealth before its first partition in 1772 , Russian liberals and radicals, to a certain extent, were ready to consider only the autonomy or independence of "ethnographic Poland" conceding the possibility of national referendum about the state affiliation of the disputed territories. The events in Russia and Poland determined changes in the views on acute problems of the Russian-Polish co-existence. The author exemplifies this statement by the evolution in political positions on the Polish question of a famous Russian émigré and constitutionalist P. V. Dolgorukov. When he edited the journal "Budushchnost" ("Future") in 1860-1861, he advocated autonomy of "ethnographic Poland", at the end of 1862 - the middle of 1863 he joined the supporters of independent "ethnographic Poland" and referendum on the state affiliation of contemporary Lithuania, Belorussia and Right-Bank Ukraine, and after the suppression of the Polish rebellion in 1863-1864, the émigré turned to his previous position. By this time, it had become evident that despite the disagreement between "the White" and "the Red" in the Polish national movement, politically active Poles were united in their understanding of one issue - "the Polish-Lithuanian Commonwealth from the sea to the sea". However, this view was inadmissible for the Russian liberals and even revolutionaries, let alone conservatives. This maximalism delayed the return of Poland to the European political map not only as an independent state but also as a political autonomy modelled on Finland of the $19^{\text {th }}$ century.

Keywords: Poland, liberalism, P. V. Dolgorukov, maximalism, independence.

Leonid Yu. Gusman - Doctor in History, St. Petersburg State University of Aerospace Instrumentation, 67, Bolshaya Morskaya ul., St. Petersburg, 190000, Russian Federation; Visiting Researcher, St. Petersburg State University, 7-9, Universitetskaya nab., St. Petersburg, 199034, Russian Federation; blummer@mail.ru

Леонид Юрьевич Гусман - д-р ист. наук, Государственный университет аэрокосмического приборостроения, Российская Федерация, 190000, Санкт-Петербург, ул. Большая Морская, 67; приглашенный исследователь, Санкт-Петербургский государственный университет, Российская Федерация, 199034, Санкт-Петербург, Университетская наб., 7-9; blummer@mail.ru

This research was supported by the grant No. 19-18-00073 "National Identity in the Imperial Politics of Memory: History of The Grand Duchy of Lithuania and the Polish-Lithuanian State in Historiography and Social Thought of the $19^{\text {th }}-20^{\text {th }}$ centuries" of the Russian Science Foundation.

Исследование выполнено в рамках гранта № 19-18-00073 «Национальная идентичность в имперской политике памяти: история Великого княжества Литовского и Польско-Литовского государства в историографии и общественной мысли XIX-XX вв.» Российского научного фонда.

(C) Санкт-Петербургский государственный университет, 2019 


\section{Польский вопрос глазами русских либералов-конституционалистов накануне и во время январского восстания}

Л. Ю. Гусман

Для цитирования: Gusman L. Yu. The Polish Question Through the Eyes of Russian Liberal Constitutionalists on the Eve and During the January Uprising // Вестник Санкт-Петербургского университета. История. 2019. Т. 64. Вып. 4. С. 1213-1225.

https://doi.org/10.21638/11701/spbu02.2019.403

Статья посвящена анализу идейных позиций русских либералов-конституционалистов по польскому вопросу в 1860 -е гг. Автор приходит к выводу о том, что взаимное непонимание между российскими и польскими публицистами заключалось в различном восприятии польской проблемы. Если польская сторона полагала, что необходимо восстановление «исторической Польши» в границах Речи Посполитой до первого ее раздела в 1772 г., то российские либералы и частично радикалы были готовы рассмотреть только возможность автономии или независимости «этнографической Польши», допуская возможность общенародного референдума о государственной принадлежности спорных территорий. В зависимости от событий в России и Польше менялись и взгляды на острые проблемы русско-польского сосуществования. В качестве примера автор обращает внимание на эволюцию политический позиций по польскому вопросу известного эмигранта-конституционалиста П. В. Долгорукова. Когда он редактировал журнал «Будущность» в 1860-1861 гг., то высказывался за автономию «этнографической Польши», в конце 1862 г. - середине 1863 г. Долгоруков присоединился к сторонникам независимости «этнографической Польши» и референдума о государственной принадлежности современных Литвы, Белоруссии и Правобережной Украины, после же подавления Польского восстания 1863-1864 гг. эмигрант вернулся к своим убеждениям первого периода. К тому времени стало понятно, что при всех разногласиях между «белыми» и «красными» в польском национальном движении существует вопрос, по которому среди политически активных поляков существовало неоспоримое единомыслие: «Речь Посполитая от моря и до моря». Но эта позиция была абсолютно неприемлема для русских либералов и даже революционеров, не говоря уже о консерваторах. Такой максимализм надолго отсрочил возвращение Польши на политические карты Европы не только как независимого государства, но и как политической автономии по образцу Финляндии XIX в.

Ключевые слова: Польша, либерализм, Долгоруков, максимализм, независимость.

The Polish question was an acute issue for the Russian social thought in the $19^{\text {th }}$ century. The problem of Poland's existence within Russia took different forms at different stages. Thus, while partitions of the end of the $18^{\text {th }}$ century practically didn't include the territory of ethnographic Poland into the Russian Empire, in 1815, Russia, according to K.F. Golovin, "had the misfortune or imprudence of annexing not only marginal provinces of the former Poland, but its core" 1 - the Kingdom of Poland, which after the suppression of the Polish rebellion in 1830-1831 and the abolition of the constitution of 1815 became the constant source of tension for Russia.

The beginning of the 1860s - "The Great reforms" accompanied by the "crisis of the elites" and heightened political tension; a surge of constitutional movement in the Empire and the establishment of representative government in western and central Europe; the

${ }^{1}$ Golovin K. F. Moi vospominaniia. Vol. 1. St. Petersburg, 1908. P. 100. 
victory of Italian national movement perceived as a model for emulation by other peoples deprived of independence - actualized the Polish question. The main problem lay in the fact that while the majority of the Russian society was ready to consider the separation of "ethnographic" Poland within the boundaries of 1815, all numerous groups of Polish emigrants without exception consented only to the independence of "historic" Poland within the boundaries of 1772. Therefore, the issue of status of Western Krai and Lithuania came to the fore. An illustrative example of unsuccessful attempts at reaching a compromise in the Polish question, mutually acceptable by all sides of the conflict, was the position of the most moderate of oppositional proclamations of the beginning of the 1860s (1861) "Velikoruss" (The Great Russian) and the views of the most radical among Russian liberals an émigré P. V. Dolgorukov².

The compilers of "Velikoruss" considered it necessary to immediately grant independence to Poland and to withdraw Russian troops from there. The authors of the proclamation couldn't reconcile liberal changes in Russia with the occupation of Poland ${ }^{3}$.

The authors held out the hope shared by many radical journalists, predominantly emigrants, at the beginning of the 1860s that aristocratic tendencies in the Polish national movement would fade: "Polish patriots decided to give away lands to peasants, despite the attempts of our government to fuel hostility between Polish estates, peasants know about it and are inspired by patriotism, and therefore, it is impossible for us now to defeat Polish uprising" 4 . This was far from reality: low activity of the most part of Polish rural population played a decisive role in relatively fast suppression of the rebellion of 1863-1864, however, the authors of "Velikoruss" could not foresee future disappointment, and were also unable to predict the emancipation reform in Poland and Western Krai in 1864 successfully implemented by the Russian authorities in order to ensure support of Polish and Lithuanian peasants ${ }^{5}$.

The demand for Polish independence was made categorically and was not new to socialist and liberal movements in the Russian social thought in the $1850-1860 \mathrm{~s}^{6}$. With regard to this, a section of the proclamation devoted to the prospective status of Western Krai was more original. It stated that "the population of southern Russia should be granted

${ }^{2}$ For more details on liberal-constitutional views of P.V.Dolgorukov, see: Gusman L. Yu.: 1) V teni "Kolokola". Russkaia liberal'no-konstitutsionalistskaia emigratsiia i obshchestvennoe dvizhenie v Rossii (1840-1860 gg.). St. Petersburg, 2004. P. 134-333; 2) Stranitsy istorii russkogo liberalizma. St. Petersburg, 2010. P. 18-112; 3) Ocherki istorii i ideologii russkogo konstitutsionalizma "Epokhi velikikh reform". St. Petersburg, 2017. P.5-159; Bakhrushin S. V. "Respublikanets-kniaz" Petr Vladimirovich Dolgorukov // Dolgorukov P.V. Peterburgskie ocherki. Pamflety emigranta. 1860-1867. Moscow, 1934. P. 5-102; Sladkevich N. G. Ocherki istorii obshchestvennoi mysli Rossii v kontse 50-kh - nachale 60-kh godov XIX veka. Leningrad, 1962. P.114-118; Eidel'man N. Ya. Gertsen protiv samoderzhaviia. Sekretnaia politicheskaia istoriia Rossii XVIII-XIX vekov i Vol'naia pechat'. Moscow, 1973. S.254-300; Ermolaev I. N. Zhizn' i bor'ba kniazia Petra Dolgorukova. Pskov, 2001. P. 113-305.

3 Chernyshevskii N. G. Velikoruss. No. 2 // Chernyshevskii N.G. Pis'ma bez adresa. Moscow, 1983. P. 307-308,

${ }^{4}$ Ibid. P. 308.

${ }^{5}$ For details, see: Kostiushko I. I. Krest'ianskaia reforma 1864 g. v Tsarstve Pol'skom. Moscow, 1962.

6 See, for example: Gertsen A.I. Rossiia i Pol'sha // Gertsen A. I. Sobranie sochinenii v 30 tomakh. Vol. XIV. Moscow, 1958. P.7-59; Bliummer L. P. Russko-pol'skii vopros // Svobodnoe slovo. 1862. Iss. 1. P. 9; Pogodin M. P.: 1) Zapiska o Pol'she (1854) // Pogodin M. P. Pol'skii vopros. Moscow, 1868. P. 36; 2) Zapiska o Pol'she (1856) // Pogodin M. P. Pol'skii vopros. Moscow, 1868. P. 54; Chicherin B. N. Ob obshchikh nachalakh evropeiskoi politiki i v osobennosti o vneshnei politike Rossii // Rossiiskii arkhiv. 2004. Iss. MMIII. P. 316-318. 
complete freedom to determine its fate according to its will" 7 . Nevertheless, the authors of the proclamation anticipated a possible polemic reaction to this demand on the part of those who supported other ideas of "Velikoruss" and therefore reserved the solution to the status of the Ukraine for years to come ${ }^{8}$.

Comparing views of P. V. Dolgorukov on the future of Poland and Western Krai with those of "Velikoruss", it is possible to find affinity between them. It was a matter of principle for "Velikoruss" to grant independence to the Kingdom of Poland. It is noteworthy that P.V. Dolgorukov in line with authors of the proclamation recognized inextricable connection between the Polish and constitutional questions and the necessity to grant at least autonomy to Poland. In the first issue of "Budushchnost" ("Future"), its editor claimed: "The abolition of Polish constitution is the greatest injustice. With autocracy in the Kingdom of Poland, there is no chance of abolition of autocracy in Russia. On the other hand, presently, given the development of enlightenment and contemporary attitudes in Russia, the current state of affairs in Europe, and in light of different events, autocracy in Russia cannot hold out with the constitution in Warsaw. That is why we sincerely and eagerly support the restoration of constitution in the Kingdom of Poland. All sensible Russians understand that the Poles are not our enemies but brothers, that we have a common adversary against whom it is necessary to fight a tireless war. This adversary is the form of government based on abuse of power, autocracy, repression and extortion" ${ }^{\prime \prime}$. It should be noted that for Dolgorukov the main criterion for the attitude to pivotal issues, including the Polish question, was concerned with the possibility of a certain event or problem to do away with absolutism. For the Prince, all issues paled in comparison with the introduction of the constitution. The opinion of "Velikoruss" was the same as it set the "main goal" to "strengthen the constitution here", i.e., in Russia ${ }^{10}$. Their arguments in proclamation for granting autonomy to Poland are almost identical with those put forward by Dolgorukov:

Dolgorukov P. V.: "The Constitution of 1815 was granted by Alexander following the solemn promise given first to the Poles and afterwards - at Vienna Congress, and to the whole Europe. He vowed to abide by it himself and on behalf of his successors. Nikolay I Pavlovich also swore on the New Testament. The Poles rebelled against him for his constant violation of the constitution. He accused them of oath-breaking. How could he forget, punishing them, and often severely, that he himself violated his own oath? ${ }^{11}<\ldots>$ All sensible Russians eagerly wish for the constitution of 1815 to be restored in the Kingdom of Poland as currently, with the constitution in Warsaw, the autocracy in Petersburg cannot hold out, and this is what we want"12.

"Velikoruss": "While in one part of the state the authority over the civilized people is based on the system of military despotism, the government is unable to reject this system in other parts of the state as well. $<\ldots\rangle$ Liberation of Poland is in the interest of Russian freedom. $<\ldots>$ Our authority over Poland is kept only by the violation of all the conditions under which the Kingdom of Poland was annexed to Russia at Vienna Congress. We pledged then that Poland would have the constitution, complete independence of its own

7 Chernyshevskii N. G. Velikoruss. No. 2. P. 308.

8 Ibid.

9 Dolgorukov P. V. O Tsarstve Pol'skom // Budushchnost'. 1860. 15 sentiabria. P. 5.

${ }^{10}$ Chernyshevskii N. G. Velikoruss. No. 2. P. 309.

11 Dolgorukov P. V. O Tsarstve Pol'skom. P. 5.

12 Dolgorukov P. V. O nyneshnikh sobytiiakh v Tsarstve Pol'skom // Budushchnost'. 1861. 12 aprelia. P.76. 
government and its own national army. We went back on our word. We remain liars in the eyes of the whole Europe"13.

The abovementioned statements share both strongly pronounced moralism of the arguments concerning references to the decisions of Vienna Congress violated by Russia, according to the authors, and the belief in the impossibility of coexistence of Warsaw constitution with autocracy in Saint Petersburg, and inevitable collapse of Russian absolutism in the case of granting representative government to Poland. Another similarity between the views of the Prince and the compilers of "Velikoruss" was the conviction that the Polish movement for independence was of liberal, non-aristocratic nature. Disagreeing with the author of one pro-government journal who accused the organizers of riots in Warsaw in 1861 in aristocratism, P. V. Dolgorukov expresses indignation: "Imminent and beneficial consequences of unrest in Poland will be evident soon: complete liberation of peasantry, granting civil equality to Jews and full equality of all Poles under the law, and this movement aimed at such noble causes, the author labels reactionary!" 14 Thus, the admission of the Prince that "annexing the Kingdom of Poland to Russia is not advantageous but positively damaging" was quite consistent and could satisfy supporters of "Velikoruss". However, it was not coincidental either that he disagreed with the proclamation's advocacy for self-determination of Western Krai.

P. V. Dolgorukov did not deny cultural distinctness of Malorossiya (Little Russia), Belorussia and Lithuania, admitted the necessity of introducing "privileges with regard to language and nationality" 15 and wide autonomy of these territories. Nonetheless, the editor of "Budushchnost" ("Future") repeatedly published articles and letters not only condemning Polish claims to Malorossiya (Little Russia) but also stressing secondary character of the Ukrainian language and literature in comparison to the Russian culture ${ }^{16}$. The Prince rather harshly distinguished the Polish question from the Ukrainian one at the beginning of the 1860s, accepting Poland's right to independence, as did "Velikoruss", but at the same time did not agree with any other concessions: "We are absolutely indifferent to separation of the Kingdom of Poland form Russia within the boundaries of 1815 but we shudder at the mere thought of giving up one third of our country light-heartedly and pushing the borders until Pskov, Smolensk, Kaluga and Kursk. We are not philosophers to such an extent in the matters of patriotism"17. Thus, the disagreement with "Velikoruss" defending the right of Malorossiya (Little Russia) to self-determination was substantial. At the same time, the proclamation made an emphasis on the secondary character of this issue prioritizing the Polish independence, similarly to Dolgorukov's views with regard to the latter. The authors of "Velikoruss" (whoever they were personally) could count on sympathy on the part of Prince-Republican P. V. Dolgorukov in their struggle for classless constitution.

Their hopes were not shattered. In the $23^{\text {rd }}$ issue of "Budushchnost" ("Future") of December, 4 1861, the third issue of "Velikoruss" was fully published.

${ }^{13}$ Chernyshevskii N. G. Velikoruss. No. 2. P. 307.

14 Dolgorukov P. V. Dikaia knizhka o sobytiiakh v Varshave // Budushchnost'. 1861. No. 15. 4 avgusta. P. 117.

15 Dolgorukov P. V. O soiuzakh Rossii s Avstriei // Budushchnost'. 1860. No.3-4. 6 dekabria. P. 29.

16 Dolgorukov P. V.: 1) Pis'mo iz Iugo-Zapadnoi Rusi // Budushchnost'. 1861. No. 8.28 fevralia. P. 5759; 2) Pol'sha i Ukraina // Budushchnost'. 1861. No. 25. 31 dekabria. P. 198-200.

17 Dolgoroukow P. Des reformes en Russie. Paris; Bruxelles, 1862. P. 64. 
The mere fact of its appearance signaled Dolgorukov's approval as he never published the material with which he disagreed. This was his principal position. The editor of " $\mathrm{Bu}$ dushchnost" ("Future") wrote in the $23^{\text {rd }}$ issue: "The journal is not a compendium for articles of different trends. The journal, especially the one founded abroad, overseas, has to set a clear aim otherwise it will become gibberish and ridiculous. Our goal is to make a contribution, small, moderate but zealous, to the process of replacing autocracy in Russia with constitution. Following this path, we are obliged to comply with necessary conditions which on no account can we violate, therefore, we can never publish anything that goes contrary to our beliefs, even when the article was sent by someone who we respect"18. "Velikoruss" met the criterion for publication put forward by Dolgorukov as it was an explicitly constitutional document, and, thus, did not contradict the tendency of "Budushchnost" ("Future"). The Prince attached so much importance to the proclamation that placed an extensive preface whose structure was subdivided into three parts: the first one outlined political programme published in the second and partly in the third issues of "Velikoruss" - which, at least on the surface, was indicative of his affinity with "Committee": "We received from Saint Petersburg the third issue of "Velikoruss" with the request to publish it in "Budushchnost", which we are eagerly carrying out. We agree with "Velikoruss":

A) that autocracy in Russia should be replaced by constitutional government;

B) that educated people should begin this great transition, should unite their efforts and do everything in their power to ensure the introduction of the constitution;

C) that a peaceful outcome, if possible, is more beneficial that the path of violence;

D) that peasants should keep their allotments of land;

E) that estate owners should be compensated by the state and that the amount should be moderate;

F) that annexing the Kingdom of Poland to Russia is not advantageous but positively damaging as the military situation requires spare troops, and state and military measures, which are taken by the government in Poland, uncivilized measures, blemish the reputation of Russia in the public opinion of the universe"19.

So Dolgorukov went along with "Velikoruss" as far as three fundamental questions raised in the proclamation: peasants, Polish question and constitution.

The second section of the article, however, revealed quite serious disagreement between the Prince and the Committee with regard to the issue of the future status of Malorossiya (Little Russia). The evolution of the journalist's views will be elaborated further but here suffice it to say that Dolgorukov rejected any projects of separation of the Ukraine from Russia in the article, resorting to various rhetorical strategies in detailed manner: "We cannot agree with the suggestion described in the second issue of "Velikoruss" to yield to all demands of the Poles irrespective of justice, history and ethnography" 20 . It is noteworthy that his divergence was not principal. The Ukrainian question was deemed secondary in comparison with other acute problems, especially, with the fate of Poland, in the second issue of "Velikoruss". Moreover, in the third issue of "Velikoruss", as well as in the attached project of the address to the Emperor, there was no mentioning of the right of Malorossiya (Little Russia) to self-determination. I believe that this omission was not

18 Dolgorukov P. V. Primechanie redaktora "Budushchnosti" // Budushchnost'. 1861. No.24. 14 dekabria. P. 185.

19 Dolgorukov P. V. Tretii list "Velikorussa" // Ibid. No.23. 4 dekadria. P. 180.

20 Ibid. P. 181. 
coincidental and could be attributed to the willingness of the authors of proclamation to avoid any reason for the breakdown of a possible union between "leading progressists" and "constitutionalists". Dolgorukov was not the only contemporary for whom the problem of the status of the Ukraine was a natural obstacle for unconditional support of "Velikoruss". A prominent liberal journalist at the time, and a no less prominent conservative civil servant in the 1880s, E. M. Feoktistov, putting forward a political programme alternative to the government, entered into an argument with the proclamation in the letter to N. A. Orlov: "It seems that Malorossiya itself has not demanded the separation" ${ }^{21}$. In my view, up until the middle of the 1860s the Ukrainian question had not been looked upon as major and of high priority. That was why Dolgorukov in the final section of the article concluding a quite moderate debate with the ideas of the Committee concerning the destiny of southern Russia gave a glowing account of the third issue of "Velikoruss" and of the project of the address to the Emperor, evidently distinguishing them from the previous issues of the proclamation. At the same time, the Prince implied that he expressed not only his own opinion but spoke on behalf of constitutional party whose support "Velikoruss" was seeking: "As for the third issue of "Velikoruss", we are willingly and proudly publish this product of underground press in Russia, the product which is very young, having emerged only yesterday but full of serious thoughts, compelling logic and remarkable by the fact that it exudes the spirit of controlled energy, the energy that is based on belief in success, the conviction which is always close to the very success. The belief is strong, very strong, and there is a lot of faith in its own might and in the future success in the third issue of "Velikoruss". We recommend all our compatriots, whatever their political views, to read it attentively, to devote great attention and impartial consideration to the third issue of "Velikoruss" and to the attached address to the Emperor. We especially welcome to this reading members of the monarchist constitutional party who would like this transition to be peaceful, or, at least, to do minimum damage. We broadly share the ideas and wishes of this party, and therefore draw its attention to the published here third issue of "Velikoruss" and to the attached address to the Emperor" 22 . It is noteworthy that every phrase in the given extract is well thought out. For fear that the audience might disregard the significance of the published document, P.V. Dolgorukov several times insists on reading it attentively so that the reader will take seriously the text ardently promoted by him. The author of the article appeals both to all Russians and to a more concrete audience - to his "constitutional party", whose existence during the given period was quite probable. However, one aspect suggests that the unanimity between the Prince and the Committee of "Velikoruss" was not complete. Nowhere in the texts of the article did Dolgorukov explicitly recommend acting in accordance with the proposals of "Velikoruss" or to submit the project of the address put forward by the Committee. He merely implied that such course of action was desirable. Apparently, Dolgorukov was slightly discomfited not by socio-political programme of "Velikoruss", which he generally shared, but by an arrogant attitude of the authors of proclamation to "backward constitutionalists lagging behind in their development"23. "Velikoruss" did not conceal that their political origin differed from that of "Budushchnost" although did not contradict its programme. Nonetheless, Dolgorukov

${ }^{21}$ Op. cit.: Shilov A. A. Arest M. I. Mikhailova i sud nad nim. Iz obshchestvennoi psikhologii nachala 60-kh gg. 19 stoletiia // Russkoe proshloe. 1923. Iss. 2. P. 145.

${ }_{22}$ Dolgorukov P. V. Tretii list "Velikorussa". P. 181.

${ }^{23}$ Chernyshevskii N. G. Velikoruss. No. 3 // Chernyshevskii N. G. Pis’ma bez adresa. P. 311. 
actively promoted the proclamation and translated all its three issues into French, introducing "Velikoruss" to European public opinion ${ }^{24}$. It should also be noted that the Prince meticulously working on the translation of the document, inserted some alterations, albeit insignificant. These changes largely aimed at adapting "Velikoruss" to European audience. For example, instead of the word "pugachevshchina" (Pugachev's rebellion) he used its French analogy - "jacquerie"25. There were other editorial corrections: "Velikoruss" criticized Russian Emperor for the sympathy towards "Francis of Naples"26, while Dolgorukov explained that it was the "king of Naples" 27 overthrown during the struggle for Italian unification. Besides stylistic changes in the French text of "Velikoruss", there were some that modified the proclamation. Thus, the appeal to introducing public trials was replaced by the demand to abolish corporal punishment ${ }^{28}$, and instead of "elimination of all social privileges", he used a vaguer phrase - "equality of all citizens before the law" 29 . However, the importance of such changes should not be exaggerated. They did not contradict the content of the Russian text, which, in the actual fact, contained the proposal to abolish corporal punishment, although in a different section ${ }^{30}$. Moreover, Dogorukov did not amend the fragments of the proclamation concerning the Ukrainian question, which he did not agree with.

Thus, by and large, the translation was equivalent to the original and testified to thorough work of the Prince on the French adaptation of the proclamation to European audience. This translation goes to show that he had in-depth knowledge of all three issues of "Velikoruss" and shared its main theses.

At the same time, debates with "Velikoruss" were not the last stage in the development of Dolgorukov's views on the status of Western Krai. They evolved, which has already been studied in scholarship ${ }^{31}$. When "Budushchnost" ("The Future") ceased to exist in 1861, P. V.Dolgorukov gradually tended to accept the ideas more suitable for both Polish revolutionaries and Ukrainophiles. The reasons behind these changes, in our opinion, were various. Most probably, the major one was the influence of A.I.Herzen and a young constitutional émigré L.P. Blummer devoting considerable attention to the Ukrainian theme in their writings, and a general aggravation of the situation resulting in the Polish rebellion in 1863-1864 and requiring more definite views. In addition, within the Polish national movement at the beginning of 1863, the positions of advocates for self-determination of Malorossiya (Little Russia) and Lithuania, and for more flexible approach to the proposal of restoring the Polish-Lithuanian Commonwealth within the boundaries of 1772 had temporarily strengthened ${ }^{32}$. The Prince considered these tendencies as the foundation for the compromise between Russian and Polish opponents to autocracy, and in 1863 , he started to defend the views very similar to those in "Velikoruss" with which

24 Dolgoroukow P. Des reformes en Russie... P. 286-310.

25 Ibid. P. 286.

26 Chernyshevskii N. G. Velikoruss. No. 3. P. 310.

27 Dolgoroukow P. Des reformes en Russie... P. 299.

28 Ibid. P. 296.

29 Ibid.

30 Chernyshevskii N. G. Velikoruss. No.3. P. 314.

31 Gusman L. Yu. Evoliutsiia vzgliadov P. V. Dolgorukova v emigratsii 1860-1867 gg. // Russkaia emigratsiia do 1917 goda - laboratoriia liberal'noi i revoliutsionnoi mysli. St. Petersburg, 1997. P.9-13.

32 Ot Tsentral'nogo narodnogo pol'skogo komiteta v Varshave gg. izdateliam "Kolokola” // Kolokol. 1862. 1 oktiabria. P. 1205-1206. 
he had disagreed. Responding to the beginning of the rebellion of 1863, Dolgorukov not only fully supported it but also shared previously rejected suggestions about a referendum in Western Krai and a possibility of creating independent Ukraine. His new programme, which took shape in the middle of 1863 , - the convocation of Assembly of Land, independence of Poland and the right of Malorossiya, Belorussia and Lithuania to self-determination - turned out to be identical to the ideas with regard to the Polish question put forward by organization "Zemlia i volia" ("Land and Liberty"), by N. A. Serno-Solovyevich and by N.P. Ogarev.

Dolgorukov P. V. - 1863: "1) To give up the Kingdom of Poland granting it complete freedom to be governed according to its own will and to find its own ruler wherever they wish

2) To convene Assembly of Land in Moscow, legitimate and non-restrictive for any estate; to present for consideration the project of the statute limiting the power of tsar, and to abolish autocracy.

3) In provinces of Lithuania, Belorussia and Malorossiya... to allow each county (uezd) to determine by voting what their population prefer: to remain within Russia, to be joined to Poland or to comprise an independent state of Malorossiya"33.

N. A.Serno-Solovyevich - 1863: "Finally and scrupulously do away with the old system and revive Russia. In order to do so:

1) To issue a solemn manifesto about recognition of basics of civil liberties in Russia... and to summon to Moscow representatives from the whole state to arrange domestic affairs.

2) To grant to the Poles the right to form an independent state allied with Russia under the conditions they consider fit, designating the territory within the boundaries of the current Kingdom of Poland.

3) To allow Lithuania, Belorussia and Ukraine, in accordance with the will of the population, either to send their representatives to Moscow or to form their local seims (assemblies) acting under the control of supreme power"34.

Proclamation of the organization "Zemlia i volia" ("Land and Liberty") 1863: "Let us firmly declare that we all wish for the immediate restoration of the Polish Kingdom with voluntary incorporation of those western provinces where the population by the majority of the votes express their will; obviously, not only nobility. $<\ldots>$ Having accomplished it, we will... have been able to begin the convocation of the Assembly of Land from the whole Russian territory" 35 .

N.P. Ogarev - 1863: "We, the Russian people, give Poland the liberty to do as they wish; as for Lithuania and Ukraine, we give them a choice either to join the Warsaw Seim if they wish so or - to join our Assembly of Land with the elected tsar"36.

Therefore, P. V. Dolgorukov indirectly avoided the only subject of his explicit debate with "Velikoruss" - the problem of self-determination of Malorossiya. In the abovementioned fragment there are some noteworthy details. Thus, the Prince deliberately states

${ }^{33}$ Dolgorukov P. V. Chto vidim my v Pol'she? // Listok, izdavaemyi kniazem Petrom Dolgorukovym. 1863. No. 5. Mai. P. 45.

34 Serno-Solov'evich N. A. Proshenie // Revoliutsionnoe dvizhenie 1860-kh gg. Moscow, 1932. P. 60.

35 Russkie liudi! // Literaturnoe nasledstvo. Vol.41-42. Moscow, 1941. P. 89.

36 Ogarev N.P. Chto-to budet? // Ogarev N. P. Izbrannye sotsial'no-politicheskie i filosofskie proizvedeniia. Vol. 2. Moscow, 1952. P. 124. 
the legal status and composition, equal for all estates, of the prospective Assembly of Land. In this way, he dissociated himself from Slavophilic ideas about a purely advisory nature of the Assembly and from the suggestions about a special role of representatives from nobility in the Assembly. As far as referendum is concerned, Dolgorukov was for general franchise. It might seem strange as he always opposed the principle of universal suffrage. Nonetheless, with regard to this case, it might have been attributed to his desire to predetermine the results of plebiscite in favour of Russia, otherwise, given eligibility requirements, most estate owners, Catholics or Uniates who sympathized with Poland, would have used their right to vote, and not Russian Orthodox peasants, whose number in the abovementioned provinces was considerable. It was not coincidental that the Prince predicted that if the proposed system of voting was implemented in Western Krai, Russia would lose only Kovno governorate and some uezdz (counties) of Vilna and Grodno governorates ${ }^{37}$. All in all, it can be stated that at the beginning and in the middle of 1863 , Dolgorukov, editors of "Kolokol ("The Bell") and activists of "Zemlia i volia" ("Land and Liberty") had similar views on the Polish question.

The suppression of the Polish rebellion in 1863-1864, prevalence of the "white" aristocratic party in the Polish emigration unwilling to reach any compromise even with pro-Polish Russian journalists, and disappointment with the viability and productivity of the Polish-Russian union made P.V. Dolgorukov return to his previous positions, which he stuck to during the debate with "Velikoruss".

In his last political work of 1867, the journalist summarized his thoughts of the many years on the Polish question: "I recognize remarkable patriotism of the Poles... their audacity, their readiness to make sacrifices for the sake of motherland, I recognize their right to independence within Poland, but I refuse to recognize their right to separate Russian provinces from Russia. Western governorates of the Russian Empire remained Russian from the $9^{\text {th }}$ to the $14^{\text {th }}$ centuries... Most of the nobility there is Polish, but the majority of the population is Russian" 38 . Therefore, Dolgorukov's views on relations between Russia and Poland eventually came down to two theses: independence of Poland within the boundaries of 1815 and preservation of Western Krai within constitutional and decentralized Russia. Despite certain disagreement with "Velikoruss", Dolgorukov fully supported the proclamation with regard to two fundamental aspects of their political programme: the necessity of independence for the Kingdom of Poland, and the connection between this issue and abolition of autocracy. These journalists' hopes for introduction of the constitution in Russia and reconciliation with Poland were abstract and very far from reality.

It should be taken into consideration that it was typical of the Russian radicals and liberals, to a certain extent, to be highly tolerant and condescending to the Polish demands. There were a number of reasons for it. First of all, of great importance was a guilt complex for participation in partitions of Poland and subsequent repressions aimed at defenders of the Polish-Lithuanian Commonwealth. Poland was looked upon as a victim. Moreover, the period of the 1850 s - the beginning of the 1860 s was marked by the surge in national movements. Russian liberals sympathizing with Italians and Hungarians fighting against Austrians could not but support the Poles being suppressed by the same

37 Dolgorukov P. V. Mikhail Nikolaevich Murav'ev. Biograficheskii ocherk // Dolgorukov P. V. Peterburgskie ocherki. Pamflety emigranta. 1860-1867. Moscow, 1934. P. 315.

38 Dolgorukov P. V. Pis'mo prezidentu tak nazyvaemogo Kongressa Mira // Ermolaev I. N. Zhizn' i bor'ba kniazia Petra Dolgorukova. Pskov, 2001. P. 434-435. 
Austrians and Prussians in Galicia and Poznan. Finally, there prevailed a view that Poland and Russia had one common enemy - absolutism of German origin in Saint Petersburg, hence a famous motto "For our freedom and yours".

The Polish society treated fateful question of relations with Russia differently. Their attitude was - "All or nothing!" While new emerging states in the West, such as Belgium and Greece, were ready to make unfavorable territorial concessions in order to ensure their sovereignty, Polish elites, split in all other aspects, were unanimous in their romantic maximalism. Given such tendencies, the majority of the Russian intelligentsia had no other choice but to consolidate around autocratic government, formerly hated, as the only force capable of maintaining integrity of Russia, including Malorossiya. A liberal journalist N. N. Voskoboinikov wrote in 1863 with bitterness in a pro-Polish magazine "Biblioteka Dlya Chteniya": "If the Poles can't give up primordially Russian lands, if they have claims even to Kiev so that to manage it according to their own will, they themselves assume the same role towards all Russians for which they accuse us, they encroach on our nationality, our independence, our liberty, and challenge us to create such conditions for them under which these assaults have no chance of success. The more sincerely and fully Poles will reject their insolent claims to Russian lands, the more they can hope for privileges. Dreams about Poland of 1772 seemed so inconceivable for the Russians that at first most deemed them a burst of fury; but alas!" 39 Polish emigration was split; each of its fraction, even minor, had its own press; they often had arguments turning into personal squabbles; however, there was one indisputable aspect: independent Poland within boundaries of 1772 - "historic Poland". In Russia, there was no prominent writer, even radical, who was ready to share this view. The transformation of the Kingdom of Poland into "the second Grand Duchy of Finland" with its own elected seim and wide autonomy did not take place, although at the beginning of 1860s there was a broad consensus in favour of such variant in the Russian political writing. After 1863, it was out of the question, and A. Berezovsky's attempt to assassinate the Emperor in 1867 revealed the extent of exasperation of a part of Polish emigration. Appeals to compassion towards "confused" Poles were expressed only in the marginal Russian legal press in the second half of the 1860s (while clandestine press was going through a grave crisis - after "Kolokol" (The Bell) and "Polyarnaya Zvezda" (Polar Star) ceased to exist in 1867-1868, for several years there had been no Russian influential press abroad). The defense of the rights of the Polish minority of Western Krai by the "oligarchical" newspaper "Vest" (Message) edited by V. D. Skariatin might have been unofficially approved of by the part of ruling elite of Saint Petersburg (P. A. Valyev, A. L. Potapov) but did not evoke any public sympathy — so odious were "Polish defenders" in the eyes of Russian progressists. "Polish affair" was associated with "aristocratic" and "antireformist".

It is possible to extend the scope and examine this issue within a European context: Belgium sacrificed parts of Limburg, Luxemburg and Maastricht; Greece - the majority of its legendary islands and Thessaly - but these countries not only ensured their independence but also introduced into international relations in the $19^{\text {th }}$ century the principle of the right of nations to self-determination. It is also noteworthy that for Greece it proved to be a far-sighted and effective policy as eventually the territories which had been "rejected" were joined to it. Another, later, example is Ireland's experience when

\footnotetext{
39 Voskoboinikov N. N. Pol'skoe delo // Biblioteka dlia chteniia. 1862. Vol. 177. P.7.
} 
their leaders of the beginning of the 1920s postponed the problem of Ulster to "indefinite future" for the sake of independence of the Catholic part of Erin. A different fate awaited the annexed part of Poland - the rebellion of 1863-1864 resulted in transformation of the Kingdom of Poland into Privislinsky krai and weakened Polish influence in Western Krai and North-Western Krai. Political romanticism can arouse admiration by its readiness for heroism and sacrifice; however, setting unfeasible goals, it can turn into a suicidal choice. Despite appeals from some Warsaw intellectuals of the 1870-1880s to "organic work" (constructive work aimed at bettering economic and cultural life), and persistent propaganda by V.D. Spasovich and his associates aimed at "real politics", even after the disaster of 1864, a considerable part of the elites of the former Polish-Lithuanian Commonwealth still remained maximalist. The offer of a friendly hand on the part of Russian liberals at the beginning of the 1860s hung in the air.

Thus, the motto of Polish aristocrats "All or nothing!" put paid to the national revival of the Polish state and delayed the return of Poland to the European political map.

For the Russian constitutional movement Polish irreconcilability was also fateful. Oppositional social environment in Moscow and Saint Petersburg at the beginning of 1863 changed into loyalist atmosphere in 1864. The rebellion in the Kingdom of Poland brought about the state of "anabiosis" of liberal opposition, which used to be non-conformist and critical. It is evident that at the beginning of the 1860 s there was a considerable sociopolitical movement, in Russia and among emigrants, aspiring to influence the affairs in the country. It can be called "liberal constitutionalism" or "radical liberalism". Their followers shared demands for immediate introduction of the constitution, abolition of estates privileges, freedom of press and conscience, decentralization, compulsory purchasing of peasantsobligations by the state, and independence of Poland (the question of the status of Western Krai was not considered to be of importance as the extent of Polish radicalization with regard to territorial issue was underestimated). At the same time, liberal constitutionalists defended inviolability of private property and restriction on economic activity of the state.

Moderate socialists - the authors of "Velikoruss", not regarding overthrowing of the contemporary economic system as the current question or the question of the near future, and being ready for compromises for the sake of political freedom in Russia, ameliorating peasants' fate, and Polish independence - sought to find common ground with this movement. P. V. Dolgorukov and his allies in Russia accepted this union, not without hesitation, and tried to abide by its conditions. It can be proved by the fact that the third issue of "Velikoruss" was published in the constitutional edition "Budushchnost" ("Future") by P.V.Dolgorukov - (earlier than in "Kolokol"), and by the absence of disagreement between the authors of "Velikoruss" and P. V. Dolgorukov with regard to major issues of Russian political life, which was no coincidence. The collapse of absolute monarchies in Western Europe (Tuscany, Parma, Modena, The Kingdom of the Two Sicilies, introduction of constitution in the Austrian Empire) was perceived as a prelude to the demise of unlimited monarchy in Russia. The authorities had to manoeuver and were preparing to make serious concessions to constitutionalists. At the same time, there was a prevalent conviction in the Russian political thought that the transition of the country to representative government was imminent. Only the pace of movement towards constitution was the subject of debates. Given the atmosphere, it seemed that the alliance between oppositional forces based on the political platform mutually acceptable for socialists and 
liberals was sufficient in order for the tsar to abdicate. "Velikoruss" put forward this programme. Its authors, Republicans and, most probably, socialists, recognized a possibility of constitutional monarchy, whereas P. V. Dolgorukov, on behalf of constitutionalists, compromised on peasant and Polish questions. A. I. Herzen and N. P. Ogarev supported it, albeit not without hesitation. Nonetheless, the views of socialists and liberals differed, and their union was not stable. In addition, only few constitutionalists - some emigrants, for example, P. V. Dolgorukov, and some nobility from Tver - were ready to resolutely break away from autocracy. The majority of their associates didn't extend their activities beyond conversations in parlours and allusions in censored press to benefits of people representation over bureaucratic absolutism. Thus, an attempt in 1861-1862 to create anti-autocratic bloc of socialists and left-wing liberals failed. Tough attitudes of Polish "Red" and especially "White" contributed to strengthening the unlimited monarchy and to weakening the ideology which was ready for compromises with the Polish elite. As it is often the case in history, maximalism proved to be a short-sighted and suicidal strategy.

\section{References}

Bakhrushin S.V. "Republican Prince" Petr Vladimirovich Dolgorukov. Dolgorukov P. V. Peterburgskie ocherki. Pamflety emigranta. 1860-1867. Moscow, Sever Publ., 1934, 474 p. (In Russian)

Eidelman N. Ya. Herzen Against the Autocracy. The Secret Political History of Russia of the $18^{\text {th }}-19^{\text {th }}$ Centuries and the Free Press. Moscow, Mysl' Publ., 1973, 317 p. (In Russian)

Ermolaev I. N. The Life and Struggle of Prince Peter Dolgorukov. Pskov, [S. n.] 2001, 440 p. (In Russian)

Gusman L. Yu. Evolution of the Views of P.V.Dolgorukov in exile 1860-1867. Russkaia emigratsiia do 1917 goda - laboratoriia liberal'noi i revoliutsionnoi mysli. Eds Y. Sherrer, B. Anan'ich. St. Petersburg, Evropeiskii Dom Publ., 1997, pp. 6-20. (In Russian)

Gusman L.Yu. In the shadow of the "Bell". Russkaia liberal'no-konstitutsionalistskaia emigratsiia $i$ obshchestvennoe dvizhenie v Rossii (1840-1860 gg.). St. Petersburg, Herzen State Pedagogical University of Russia Press, 2004, 376 p. (In Russian)

Gusman L. Y. Pages of the History of Russian Liberalism. St. Petersburg, Izd-vo Politekhn. un-ta Publ., 2010, 152 p. (In Russian)

Gusman L. Yu. Essays on the History and Ideology of Russian Constitutionalism "Epochs of Great Reforms". St. Petersburg, Izd-vo Politekhn. un-ta Publ., 2017, 190 p. (In Russian)

Kostiushko I. I. Peasant Reform of 1864 in the Congress Poland. Moscow, Akademii nauk SSSR Press, 1962, 494 p. (In Russian)

Sladkevich N.G. Essays on the History of Social Thought in Russia in the late 50s - early 60s of the $19^{\text {th }}$ Century. Leningrad, Leningrad University Press, 1962, 284 p. (In Russian)

Shilov A. A. The Arrest of M. I. Mikhailov and his Trial. From Social Psychology of the Early $60^{\text {th }}$ of the $19^{\text {th }}$ Century. Russkoe proshloe, 1923, iss. 2, pp. 140-162. (In Russian) 